\title{
Sensory processing disorders among substance dependents
}

\author{
Batya Engel-Yeger \\ Faculty of Social Welfare \& Health Sciences, University of Haifa, Mount Carmel, Haifa, Israel
}

\begin{abstract}
Purpose: (1) To compare sensory processing patterns as expressed in daily life between substance dependents and typical controls; (2) profile the prevalence of sensory processing disorders (SPD) among substance dependents; and (3) examine gender effect on SPD within and between groups. Methods: Two hundred ninety people aged 19-64 participated in this study. The study group included 145 individuals who lived in the community or took part in an outpatient program because of addiction to drugs/alcohol and had been clean for over three months. The control group included 145 individuals who were not exposed to drugs or alcohol on a regular basis and did not suffer from addictive behavior. All participants filled a demographic questionnaire. Those who met the inclusion criteria completed the Adolescent/Adult Sensory Profile (AASP) so that their sensory processing patterns could be assessed. Results: When comparing both groups, the study group showed greater sensory sensitivity and significantly higher prevalence of SPD. Significant group/gender interaction was found in regard to sensation seeking. Discussion: SPD among substance dependents may be expressed in daily life by either hypersensitivity or hyposensitivity. The behavioral outcomes reflected by the AASP support neurophysiological manifestations about SPD of substance dependents. The evaluation process of substance dependents should refer to their sensory processing abilities. In case SPD is diagnosed, Occupational Therapy and specific sensory-based interventions should be considered in order to fit the specific needs of individuals and enhance their performance, meaningful participation, and quality of life.
\end{abstract}

Keywords: Street Drugs, Sensation, Activities of Daily Living.

\section{Alteraçóes no processamento sensorial entre dependentes químicos}

Resumo: Objetivo: (1) Comparar os padrões do processamento sensorial em atividades cotidianas de dependentes de substâncias psicoativas e de participantes do grupo controle típico. (2) Delinear a prevalência dos transtornos de processamento sensorial (SPD) entre dependentes de substâncias psicoativas. (3) Examinar a influência do gênero nos SPD. Métodos: Participaram 290 pessoas com idade entre 19 e 64 anos. O grupo incluiu 145 indivíduos com histórico de dependência de drogas/álcool que viviam na comunidade ou que participavam de um programa ambulatorial e estavam abstinentes há mais de três meses. O grupo controle incluiu 145 indivíduos que não estiveram expostos a drogas ou álcool regularmente e não apresentavam sintomas de dependência química. Todos os participantes preencheram um questionário demográfico. Aqueles que atenderam aos critérios de inclusão completaram o protocolo Adolescent/Adult Sensory Profile (AASP) a fim de que seus padrões de processamento sensorial pudessem ser avaliados. Resultados: O grupo de estudo apresentou maior sensibilidade sensorial e prevalência significativamente maior dos SPD. Uma interação significativa entre sexo e grupo foi encontrada em relação à busca de sensações. Discussão: Os SPD podem manifestar-se nas atividades cotidianas, entre dependentes de substâncias psicoativas, por hipersensibilidade ou hipossensibilidade. Os resultados comportamentais refletidos pelo AASP corroboram às manifestações neurofisiológicas associadas aos SPD em dependentes de substâncias psicoativas. Os processos de avaliação devem considerar as habilidades de processamento sensorial. Quando um SPD for diagnosticado, intervenções sensoriais específicas devem ser consideradas, a fim de atender às necessidades do indivíduo e melhorar seu desempenho, participação e qualidade de vida.

Palavras-chave: Drogas Ilícitas, Sensação, Atividades Cotidianas.

Autor para correspondência: Batya Engel-Yeger, Faculty of Social Welfare \& Health Sciences, University of Haifa, Mount Carmel, Haifa 31905 Israel, e-mail: bengel@univ.haifa.ac.il

Received on 9/5/2013; Revision on 1/27/2014; Accepted on 5/4/2014. 


\section{Introduction}

Using psychoactive substance is a universal phenomenon across all strata of society. According to the World Health Organization (2013) substance abuse refers to the harmful or hazardous use of psychoactive substances, including alcohol and illicit drugs. Addiction to psychoactive substances is expressed in a dependence syndrome - a cluster of behavioral, cognitive, and physiological phenomena that develop after repeated substance use and that typically include a strong desire to take the drug, difficulties in controlling its use, persisting in its use despite harmful consequences, a higher priority given to drug use than to other activities and obligations, increased tolerance, and sometimes a physical withdrawal state (http://www.who.int/ topics/substance_abuse/en/).Substance use addiction also implies the existence of the initial increase of tolerance to the addictive agent (RASSOOL, 2002). Addiction leads to a vicious cycle that significantly impairs function, participation and well being.

Research and clinical experience reveal no single etiological factor for why some people use drugs and others do not; why part of them becomes dependent on a substance and what is the reason for choosing specific drugs (drug-of-choice). Probably, several factors play a role in the phenomenon called addiction. According to the biopsychosocial model a combination of psychological, biochemical, genetic and environmental factors play a role in addiction causation and consequences (VAB WORMER; DAVIS, 2003).

In regard to the biological aspect of addiction, studies describe dysfunctions in the central nervous system of substance dependents, that may also negatively influence the function of their ability to process sensory information adaptively (MARCO; FUENTEMILLA; GRAU, 2005). Sensory processing involves the registration, modulation and the internal organization of sensory input (HUMPHRY, 2002). Sensory processing abilities shape cognitive perception, emotions and behavior (CALVERT; SPENCE; STEIN, 2004). Thus, people must constantly process incoming sensory information to effectively interact with their environment.

When considering the psychological factors (which received a lot of attention in the literature of addiction), four problematic personality traits place people at risk for substance use: hopelessness (WOICIK et al., 2009) anxiety (KRANK et al.; 2010), impulsivity (DIEHEM; ARMATAS , 2004) and sensation seeking (DAWE; LOXTON, 2004). SPD is frequently related to these personality traits
(ENGEL-YEGER; DUNN, 2011a; BEN-AVI; ALMAGOR; ENGEL-YEGER, 2012).

Sensory processing disorders (SPD) are characterized by over- or underresponsiveness to environmental stimuli due to high or low neurological threshold to sensory stimulations (DUNN, 1997). SPD are known to dull adaptive responses to environmental demands, negatively affect meaningful engagement in daily occupations (HUMPHRY, 2002), and impair well being (PARHAM; MAILLOUX, 2001). Thus, the person's psychological and the behavioral strategies he/she uses to deal with sensations have a significant impact on their adaptive performance and participation in daily life activities (MILLER et al., 2007).

Dunn (1997) developed a model which refers to the interaction between the person's neurological threshold continuum to sensory stimuli and the behavioral response/self regulation continuum to sensations (DUNN, 1997). This interaction results in four sensory processing patterns: (1) Low registration - people with a high neurological threshold and passive responses. These people fail to detect sensation and do not actively seek for sensory input. (2) Sensation seeking is an active response to high neurological threshold - people with this pattern enjoy rich sensory environment and actively seek sensations. (3) Sensation avoiding is an active pattern in response to a low neurological threshold. People with this pattern actively limit their exposure to stimuli. (4) Sensitivity to stimuli - people whose behaviors are more passive with a low neurological threshold. Although they feel uncomfortable with sensations, they do not actively avoid the disturbing stimuli. People found in both patterns of overresponsiveness due to their low neurological threshold are frequently described as irritable, moody, express poor socialization.

SPD is a frequent co-morbidity of Attention Deficit Hyperactivity Disorder (ADHD) and emotional disturbances related to the extreme personality traits mentioned above (ENGEL-YEGER; DUNN, 2011a; SHOCHAT; TZISCHINSKY; ENGEL-YEGER, 2009; O'MALLEY; NANSON, 2002; LAVIOLETTE; GRACE, 2008). This raises the possibility that individuals with ADHD or emotional disturbances suffer from SPD in various modalities and in various severities.

The involvement of the central nervous system in SPD and in addictive substance use may explain the commonality between substance use and SPD (ASTELY; CLARREN, 2000). For example, alcohol exposure could compromise cortical plasticity and therefore, impair adaptive behavioral responses to 
environmental events, including those that encompass reach sensory stimuli (SCHNEIDER et al., 2008). Recordings of brain activity, using evoked response potentials (ERPs) demonstrated abnormalities in thalamo-cortical responses among cocaine abusers (LEE et al., 2003) leading to hyper-activation due to poor inhibitory control or difficulty filtering sensory information appropriately (TOMASI et al., 2007). Except for the brain structural abnormalities, the altered brain neurotransmitter functioning may also explain SPD among substance dependents. This includes decreased dopamine uptake, altered dopamine synthesis and deficits in serotonin reuptake sites (ROMANOS et al., 2008; LAVIOLETTE; GRACE, 2008; SEMPLE; MCINTOSH; LAWRIE, 2005). Larsson et al. (2009) found that decreased dopamine level impairs smell discrimination. Schneider et al. (2008) found that monkeys that were prenatal alcohol exposed consistently responded negatively and failed to habituate to repeated tactile stimuli, due to their impaired dopamine system.

Based on the above, substance use may interfere with the function of the central nervous system and as a result may lead to SPD. Yet, the very few studies that demonstrated the impaired sensory processing abilities of individuals who use addictive substance referred to specific sensory modalities, used neurophysiological assessments as brain imaging, and lack a wide understanding about the expression of these sensory processing abilities in daily life. The present study aimed to illuminate this point by characterizing the sensory processing patterns of substance dependents, as expressed in all sensory modalities and in daily living situation, by using a self report. This study also aimed to examine group $\mathrm{X}$ gender effect on sensory processing abilities.

\section{Methods}

\subsection{Participants}

290 participants were included in this study. The study group consisted of 145 individuals (112 males, 28 females; 5 missing cases), aged 19-64 $($ mean $=33.89 \pm 9.79)$ who lived in a rehabilitation community or took part in an outpatient program, due to addiction to drugs/alcohol and had been cleaned for over three months $($ mean $=3.49 \pm 1.97)$, in order to eliminate the impact of the addictive agents on the brain. Thirty eight of them had diagnosed ADHD. The control group included 145 individuals (69 males, 76 females), aged 19-59 $($ mean $=34.53 \pm 10.32)$ who were never exposed to drugs or alcohol on a regular basis and did not suffer from any addictive behavior.

\subsection{Instruments}

Demographic questionnaire which provided socio-demographic data, information about health status and about the use of addictive agents and was used to approve inclusion criteria and group membership.

The adolescent/adult sensory profile (BROWN; DUNN, 2002) - This self-measure tool is based on Dunn's model (DUNN, 1997) and refers to the behavioral responses to sensory experiences in daily life. This tool includes 60 that encompass all sensory systems (i.e. vision, taste, smell etc.). For scoring, the 60 items are sorted equally into four quadrants: Low Registration, Sensation Seeking, Sensory Sensitivity, and Sensation Avoiding (based on factor analysis), reflecting different sensory processing patterns. Each quadrant provides information on multiple sensory systems. Participants indicate how often they respond to the sensory event described in each item using a 5-point Liker scale (from 1 corresponding to "almost never" to 5 corresponding to "almost always"). The resultant score for each quadrant ranges from 5 to 75 . Norms are described for each age group (11-17; 18-64; 65 and older). This questionnaire has good internal consistency with coefficient alpha values of .692 for Low Registration, .639 for Sensation Seeking, .657 for Sensory Sensitivity and .699 for Sensation Avoiding (POHL; DUNN; BROWN, 2003).

In order to achieve a higher number of participants in each sensory performance range, the five ranges for each sensory processing quadrant presented in the AASP manual (i.e. "Much less than most people"; "Less than most people"; "Similar to most people"; "More than most people" and "Much more than most people"), were merged into three: (1) "Much less than most people" and "Less than most people" were merged and defined as "Less than most people" (representing approximately 16\% of the population, or more than one standard deviation (SD) below the mean); (2) "Similar to most people" was not changed, and represents approximately $68 \%$ of the population between -1 SD and +1 SD) (3) "More than most people" and "Much more than most people" were merged and defined as "More than most people" (representing approximately $16 \%$ of the population, or more than $1 \mathrm{SD}$ above the mean).

\subsection{Procedure}

After receiving the ethical approval of the University of Haifa for conducting this study, the study manager asked the permission of the institutes to which the participants belonged to perform the study. Advertisements calling to participate 
in a study about sensory reactivity in daily life were also published in various neighborhoods for recruiting the control group. People who answered the advertisements were asked to fill the demographic questionnaire. Those who answered the inclusion criteria were included in the study. All participants filled the AASP in a quite room in the rehabilitation community or in their homes.

\subsection{Data analysis}

The effects of gender and age on participant's AASP scores were examined by two way MANOVA. Chi square analysis was performed to examine whether significant differences existed between both groups in their demographic parameters and in the percentage of participants found in each performance range of the AASP quadrants.

The level of significance will be set on $\mathrm{p} \leq .05$.

\section{Results}

Regarding demographic parameters - groups significantly differed in gender distribution $\left(\chi_{(1)=33.87 ;}^{2}<<.001\right)$ and in education level $\left(\chi_{(1)=33.31 ;}^{2}\right.$ $\mathrm{p}<.001)$. Education level was significantly higher among the controls.

Sensory processing abilities significantly differed between groups $\left(\mathrm{F}_{4,276}=6.65, \mathrm{p}<.001, \mathrm{Eta}^{2}=.09\right)$. The study group showed greater tendency of sensory sensitivity and sensation avoiding than the controls. Table 1 summarizes the differences between groups in each AASP quadrant.

Chi-square analysis revealed that while more participants from the control group were found in the "similar to most people range" in the four AASP quadrants, significant higher percentage of participants from the study group was found in the "more than most people range" in the four AASP quadrants (see Table 2). The larger difference between the groups was expressed in sensation avoiding.

Group X gender interaction was also found to be significant $\left(\mathrm{F}_{4,276}=4.22, \mathrm{p}=.02, \mathrm{Eta}^{2}=.06\right)$. This was expressed in the sensation seeking quadrant where men in the control group showed greater seeking tendency than men in the study group. Women in the control group showed lower seeking tendency than women in the study group. Table 3 summarizes the differences between groups and genders (see Table 3).

Table 1. Difference between groups in AASP scores.

\begin{tabular}{lcccccc}
\hline & \multicolumn{2}{c}{ Study group } & \multicolumn{2}{c}{ Control group } & & \\
\cline { 2 - 7 } & Mean & SD & Mean & SD & F & Eta $^{2}$ \\
\hline Registration & 33.78 & 8.52 & 32.87 & 9.53 & 2.29 & .008 \\
Seeking & 46.39 & 9.15 & 47.88 & 7.28 & .11 & 0 \\
Sensitivity & 39.79 & 9.24 & 37.33 & 8.47 & $10.67 * * *$ & .04 \\
Avoidance & 39.97 & 9.86 & 35.76 & 7.12 & $26.28^{* * *}$ & .09 \\
\hline
\end{tabular}

*** $\mathrm{p}<.001$.

Table 2. Percentage of participants in each AASP quadrant performance range.

\begin{tabular}{lcccccccc}
\hline & \multicolumn{3}{c}{ Study group } & \multicolumn{4}{c}{ Control group } & \\
\cline { 2 - 7 } & $\begin{array}{c}\text { Less than } \\
\text { most people }\end{array}$ & $\begin{array}{c}\text { Similar to } \\
\text { most people }\end{array}$ & $\begin{array}{c}\text { More than } \\
\text { most people }\end{array}$ & $\begin{array}{c}\text { Less than } \\
\text { most people }\end{array}$ & $\begin{array}{c}\text { Similar to } \\
\text { most people }\end{array}$ & $\begin{array}{c}\text { More than } \\
\text { most people }\end{array}$ & $\chi_{(2)}$ \\
\hline Registration & 50 & 40 & 62.4 & 50 & 60 & 37.6 & $12.47^{* *}$ \\
Seeking & 58.9 & 43.2 & 65.6 & 41.1 & 56.8 & 34.4 & $8.84^{*}$ \\
Sensitivity & 52.4 & 42 & 60 & 47.6 & 58 & 40 & $8.41^{*}$ \\
Avoidance & 48 & 40.9 & 63.5 & 52 & 59.1 & 36.5 & $12.85^{* *}$ \\
\hline$* \mathrm{p} \leq .05 . * * \mathrm{p} \leq .01$. & & & & & & &
\end{tabular}

Table 3. Difference between both genders in AASP scores as presented in each group.

\begin{tabular}{|c|c|c|c|c|c|c|c|c|c|}
\hline & \multicolumn{4}{|c|}{ Study group } & \multicolumn{4}{|c|}{ Control group } & \multirow{3}{*}{$F$} \\
\hline & \multicolumn{2}{|c|}{ Men } & \multicolumn{2}{|c|}{ Women } & \multicolumn{2}{|c|}{ Men } & \multicolumn{2}{|c|}{ Women } & \\
\hline & Mean & SD & Mean & SD & Mean & SD & Mean & SD & \\
\hline Registration & 33.53 & 8.31 & 35.92 & 8.53 & 33.01 & 10.85 & 32.76 & 8.22 & 1.16 \\
\hline Seeking & 45.53 & 8.86 & 51.01 & 8.15 & 48.55 & 7.45 & 47.28 & 7.12 & $9.54 * *$ \\
\hline Sensitivity & 39.72 & 9.26 & 42.29 & 7.69 & 34.73 & 8.29 & 39.69 & 7.97 & 1.06 \\
\hline Avoidance & 39.97 & 9.72 & 42.81 & 7.41 & 34.08 & 7.32 & 37.28 & 6.61 & .03 \\
\hline
\end{tabular}

** $\mathrm{p} \leq .01$. 


\section{Discussion}

The present study aimed to profile the sensory processing abilities of substance dependents.

The study results revealed that substance dependents showed greater tendency of sensory sensitivity and sensation avoiding than the controls. This supports previous literature about hypersensitivity among substance dependents. For example, Marco, Fuentemilla and Grau (2005) found that individuals with cocaine dependency and acute ingestion of low doses of alcohol have difficulties in inhibiting auditory stimuli as expressed in "P50" measure. It was suggested that substance dependents have impaired sensory gating manifested in a widespread disturbed inhibition of sensory stimuli, in difficulties filtering the relevant stimulus and in sensory discrimination deficiencies (LEE et al, 2003; TOMASI et al., 2007).

The imbalance mechanisms related to neurotransmitters such as dopamine and serotonin may also play a role in sensory processing difficulties of substance dependents (BURKETT; YOUNG, 2012; MICZEK et al., 2011) and explain their un-adaptive behaviors that include decreased motivation and difficulties in modulation emotional responses (SCHNEIDER et al., 2008; LAVIOLETTE; GRACE, 2008; SEMPLE; MCINTOSH; LAWRIE, 2005; ZAVITSANOU; GARRICK; HUANG, 2004).

Nevertheless, while previous reports about neurophysiological manifestations of sensory reactivity among substance dependents was mainly in relation to a single modality, this study added information about the sensory processing abilities of substance dependents as expressed in all sensory modalities and in daily living situation.

The present study found that a significant higher percentage of substance dependents were found in the extreme edges of the AASP performance ranges, i.e. the "more than most people" interval in sensory processing patterns related to low neurological threshold (sensory sensitivity and sensation avoiding) but also to those related to high neurological threshold (low registration and sensation seeking). The greater tendency to both hyper and hyposensitivity may be explained by the self-medication hypothesis (KHANTZIAN, 1997). According to this hypothesis, some people seek for addictive substance as a compensatory mechanism for their un-modulated arousal level or for a relief of a particular affective state. Both over or under reactivity to sensory stimuli may lead to un-modulated arousability and to an impaired affective state. This was well described in the literature regarding people with hypersensitivity in behavioral and neurophysiological studies. For example, individuals with sensory hypersensitivity showed hyperarousal mechanisms, enhanced sympathetic nervous system reactivity and elevated activity of brain areas associated with hyperemotionality (KISLEY; NOECKER; GUINTER, 2004). This hyperemotionality provided an explanation for their anxiety, depression, irritability, etc (BERRIDGE; WATERHOUSE, 2003). While most studies referred to people with hypersensitivity, few studies found un-modulated arousal level and extreme affective states among people with hyposensitivity (JEROME; LISS, 2005). Engel-Yeger and Dunn (2011a, b) who found enhanced anxiety, elevated catastrophization and negative affect among people with low registration suggested that these affective states result from their difficulties to detect sensations. Since they do not notice sensory input in the right velocity and intensity, they might overlook sensations, experience some of them as surprising, overwhelming and un pleasant. This may cause their extreme emotional responses and even impair their affective state.

The significant group $\mathrm{X}$ gender interaction regarding sensation seeking suggests that addict men may differ in their sensory processing tendencies from addict women. This is in contrast to the report of Rupp et al. $(2003,2006)$ who examined alcohol-dependent patients. These authors claimed that SPD among substance dependents, related to olfactory identification, discrimination, and detection threshold are present independent of age, gender, depressive symptomatology, and length of abstinence.

The result of the present study according to which addict women showed the greatest tendency for sensation seeking supports the study of Engel-Yeger (2012) that evaluated sensory processing patterns among typical people. Since the literature about gender effect on sensory processing patterns is limited, additional studies on larger samples with gender matching should further examine this issue. This information may shed light on the relevance of referring to gender interaction with SPD in intervention programs.

Another point that should be considered is that although SPD was found to be more prevalent among substance dependents, it is hard to decide whether people with SPD are prone for substance use since they seek for a compensatory mechanism or whether SPD is a result of changes in brain of substance dependents. Both directions are possible. 
Indeed, the biopsychosocial model highlights that interactionism is a major component of addiction (VAN WORMER; DAVIS, 2003), meaning that cause and effect are intertwined. Thus, clinicians should notice that SPD - whether as a primary cause or as a result of substance use - negatively influence daily life and thus significantly reduces well being. The combination of substance use together with SPD makes substance dependents more vulnerable to these negative effects. It worsens the burden that they experiences when facing daily demands. Thus, it is recommended that SPD should be screened in rehabilitation program for among substance dependents.

Occupational Therapists are considered to be the main providers of sensory interventions. Moreover, the goal of Occupational Therapy is to enhance the person's performance and participation in daily life. Considering the negative impacts of substance use on the person's ability to perform and participate adequately, awareness to this issue should be elevated among Occupational Therapists (OTs). Hence, OTs should be an integral part of the therapeutic team for substance dependents. Specifically, when SPD is diagnosed, occupational therapists should understand, together with the person, how these extreme sensory patterns influence the person's life, emotional responses, social relationship, the ability to perform daily activities and meaningful participation in various daily environments.

It is important that the evaluation of sensory processing abilities will include the person's self report. This is in one line with the client centered approach (ROSENBAUM et al., 1998).When referring to sensory experiences, which are so personal to each individual, a self report such as the AASP provides the person and the therapist a more comprehensive understanding of behavioral reactions in specific conditions and environments that involve sensory stimuli (ASHBURNER et al., 2013; CRANE; GODDARD; PRING, 2009; DUNN, 2001). The awareness to one self specific sensory needs may assist the person in using the best coping strategies to deal with environmental demands, in choosing the right environmental adaptations needed for enhancing adaptive behaviors. In addition of using sensory-based interventions, the complexity of addiction stresses the benefits of multi disciplinary intervention. Such approach may decrease behavioral problems, enhance the person's performance and meaningful participation at home, at work, in the community, and elevate the person's quality of life and well being.

\section{Acknowledgments}

I would like to thank the Israeli Anti-Drug Authority for funding this study.

\section{References}

ASHBURNER, J. et al. Understanding the sensory experiences of young people with autism spectrum disorder: a preliminary investigation. Australian Occupational Therapy Journal, Melbourne, v. 60, n. 3, p. 171-180, 2013.

ASTELY, S. J.; CLARREN, S. D. Diagnosing the full spectrum of fetal alcohol exposed individuals: introducing the 4-digit diagnostic code. Alcohol and Alcoholism, Oxford, v. 34, p. 400-410, 2000. http://dx.doi.org/10.1093/ alcalc/35.4.400

BEN-AVI, N.; ALMAGOR, M.; ENGEL-YEGER, B. Sensory processing difficulties and interpersonal relationships in adults: an exploratory study. Psychology, Savannah, v. 3, n. 1, p. 70-77, 2012.

BERRIDGE, C. W.; WATERHOUSE, B. D. The locus coeruleus-noradrenergic system: Modulation of behavioral state and state-dependent cognitive processes. Brain Research Reviews, Amsterdam, v. 42, n. 1, p. 33-84, 2003. http://dx.doi.org/10.1016/S0165-0173(03)00143-7

BROWN, C.; DUNN, W. The adolescentladult sensory profile: user's manual. San Antonio: The Psychological Corporation, 2002.

BURKETT, J. P.; YOUNG, L. J. The behavioral, anatomical and pharmacological parallels between social attachment, love and addiction. Psychopharmacology, Berlin, v. 224, n. 1, p. 1-26, 2012. PMid:22885871 PMCid:PMC3469771. http://dx.doi.org/10.1007/ s00213-012-2794-x

CALVERT, G. A.; SPENCE, C.; STEIN, B. E. The handbook of multisensory processes. Cambridge: MIT Press, 2004.

CRANE, L.; GODDARD, L.; PRING, L. Sensory processing in adults with autism spectrum disorders. Autism, London, v. 13, n. 3, p. 215-228, 2009. PMid:19369385. http://dx.doi.org/10.1177/1362361309103794

DAWE, S.; LOXTON, N. J. The role of impulsivity in the development of substance use and eating disorders. Neuroscienceand Biobehavioral Reviews, New York, v. 28 n. 3, p. 43-51, 2004.

DIEHEM, R.; ARMATAS, C. Surfing: an avenue for socially acceptable risk-taking, satisfying needs for sensation seeking and experience seeking. Personality and Individual differences, Oxford, v. 36, n. 3, p. 663-677, 2004.

DUNN, W. The sensory profile: examiner's manual. San Antonio: Psychological Corporation, 1997.

DUNN, W. The sensations of everyday life: empirical, theoretical, and pragmatic considerations. American Journal of Occupational Therapy, New York, v. 55, n. 6, p. 608-620, 2001. http://dx.doi.org/10.5014/ajot.55.6.608

ENGEL-YEGER, B. Validating the adolescent/adult sensory profile and examine its ability to screen sensory processing difficulties among Israeli people. British Journal of Occupational Therapy, London, v. 75, n. 7, 
p. 321-329, 2012. http://dx.doi.org/10.4276/030802 212X13418284515839

ENGEL-YEGER, B.; DUNN, W. The relationship between sensory processing difficulties and anxiety level of healthy adults. British Journal of Occupational Therapy, London, v. 74, n. 5, p. 210-216, 2011a. http://dx.doi.org/ 10.4276/030802211X13046730116407

ENGEL-YEGER, B.; DUNN, W. The relationship between sensory processing patterns and pain catastrophizing level in healthy adults. American Journal of Occupational Therapy, New York, v. 65, n. 1, p. e1-e10, 2011b. http:// dx.doi.org/10.5014/ajot.2011.09004

HUMPHRY, R. Young children's occupations: explicating the dynamics of developmental processes. American Journal of Occupational Therapy, New York, v. 56, p. 171-179, 2002. http://dx.doi.org/10.5014/ajot.56.2.171

JEROME, E. M.; LISS, M. Relationships between sensory processing style, adult attachment, and coping. Personality and Individual Differences, Oxford, v. 38, n. 6, p. 1341-1352, 2005. http://dx.doi.org/10.1016/j. paid.2004.08.016

KHANTZIAN, E. J. The self-medication hypothesis of addictive disorders: A reconsideration and recent applications. Harvard Review of Psychiatry, St. Louis, v. 4, n. 5, p. 231- 244, 1997.

KISLEY, M. A.; NOECKER, T. L.; GUINTER, P. M. Comparison of sensory gating to mismatch negativity and self-reported perceptual phenomena in healthy adults. Psychophysiology, Baltimore, v. 41, n. 4, p. 604-612, 2004. PMid:15189483. http://dx.doi. org/10.1111/j.1469-8986.2004.00191.x

KRANK, M. et al. Structural, concurrent, and predictive validity of the substance use risk profile scale in early adolescence. Addictive Behaviors, Oxford, v. 36, p. 37-46, 2010. PMid:20826056. http://dx.doi. org/10.1016/j.addbeh.2010.08.010

LARSSON, M. et al. Age-related loss of olfactory sensitivity: association to dopamine transporter binding in putamen. Neuroscience, Oxford, v. 161, n. 2, p. 422-426, 2009. PMid:19348872. http://dx.doi. org/10.1016/j.neuroscience.2009.03.074

LAVIOLETTE, S. R.; GRACE, A. A. The roles of cannabinoid and dopamine receptor systems in neural emotional learning circuits: implications for schizophrenia and addiction. Cellular and Molecular Life Sciences, Basel, v. 63, n. 14, p. 1597-1613, 2008. PMid:16699809. http:// dx.doi.org/10.1007/s00018-006-6027-5

LEE, J. H. et al. Abnormal brain activation to visual stimulation in cocaine abusers. Life Sciences, Amsterdam, v. 73, n. 15, p. 1953-1961, 2003. http://dx.doi.org/10.1016/ S0024-3205(03)00548-4

MARCO, J.; FUENTEMILLA, L.; GRAU, C. Auditory sensory gating deficit in abstinent chronic alcoholics. Neuroscience Letters, Amsterdam, v. 375, n. 3, p. 174-177, 2005. PMid:15694255. http://dx.doi. org/10.1016/j.neulet.2004.11.017

MICZEK, K. A. et al. Escalated or suppressed cocaine reward, tegmental BDNF, and accumbaldopamine caused by episodic versus continuous social stress in rats. Journal of Neuroscience, Baltimore, v. 31, n. 27, p. 9848-9857, 2011. PMid:21734276 PMCid:PMC3144494. http://dx.doi. org/10.1523/JNEUROSCI.0637-11.2011

MILLER, L. J. et al. Concept evolution in sensory integration: a proposed nosology for diagnosis. American Journal of Occupational Therapy, New York, v. 61, n. 2, p. 135-140, 2007. http://dx.doi.org/10.5014/ajot.61.2.135 O’MALLEY, K. D.; NANSON, J. Clinical implications of a link between fetal alcohol spectrum disorder and attention-deficit hyperactivity disorder. Canadian Journal of Psychiatry, Ottawa, v. 47, n. 4, p. 349-354, 2002.

PARHAM, O. D.; MAILLOUX, Z. Sensory integration. In: CASE-SMITH, J. (Ed.). Occupational therapy for children. 4th ed. St. Louis: Mosby, 2001. p. 329-381.

POHL, P. S.; DUNN, W.; BROWN, C. The role of sensory processing in the everyday lives of older adults. OTJR: Occupation, Participation and Health, Thorofare, v. 23, n. 3, p. 99-106, 2003.

RASSOOL, G. H. Dual diagnosis: substance misuse and psychiatric disorders. Oxford: Blackwell Science, 2002.

ROMANOS, M. et al. Improved odor sensitivity in attention-deficit/hyperactivity disorder. Biological Psychiatry, New York, v. 64, n. 11, p. 938-940, 2008. PMid:18814862. http://dx.doi.org/10.1016/j. biopsych.2008.08.013

ROSENBAUM, P. et al. Family-centered service: a conceptual framework and research review. Physical of Occupational Therapy in Pediatrics, England, v. 18, n. 1, p. 1-20, 1998.

RUPP, C. I. et al. Executive function and memory in relation to olfactory deficits in alcohol-dependent patients. Alcoholism, Clinical and Experimental Research, England, v. 30, n. 8, p. 1355-1362, 2006. PMid:16899038. http:// dx.doi.org/10.1111/j.1530-0277.2006.00162.x

RUPP, C. I. et al. Reduced olfactory sensitivity, discrimination, and identification in patients with alcohol dependence. Alcoholism, Clinical and Experimental Research, England, v. 27, n. 3, p. 432-439, 2003. PMid:12658108. http://dx.doi.org/10.1097/01.ALC.0000057945.57330.2C

SCHNEIDER, M. L. et al. Sensory processing disorder in a primate model: evidence from a longitudinal study of prenatal alcohol and prenatal stress effects. Child Development, Chicago, v. 79, n. 1, p. 100-113, 2008. PMid:18269511. http://dx.doi. org/10.1111/j.1467-8624.2007.01113.x

SEMPLE, D. M.; MCINTOSH, A. M.; LAWRIE, S. M. Cannabis use as a risk factor for psychosis: systematic review. Journal of Psychopharmacology, Oxford, v. 19, p. 187-194, 2005. http://dx.doi. org/10.1177/0269881105049040

SHOCHAT, T.; TZISCHINSKY, O.; ENGEL-YEGER, B. Sensory hypersensitivity as a contributing factor in the relation between sleep and behavioral disorders in normal schoolchildren. Behavioral Sleep Medicine, Mahwah, v. 7, n. 1, p. 53-62, 2009. PMid:19116801. http://dx.doi. org/10.1080/15402000802577777

TOMASI, D. et al. Thalamo-cortical dysfunction in cocaine abusers: Implications in attention and perception. Psychiatry Research, Amsterdam, v. 155, n. 3, 
p. 189-201, 2007. PMid:17582746 PMCid:PMC2265105. http://dx.doi.org/10.1016/j.pscychresns.2007.03.002

VAN WORMER, K.; DAVIS, D. R. Addiction treatment: a strengths perspective. Pacific Grove: Thomson Brooks/ Cole, 2003.

WOICIK, P. A. et al. The substance use risk profile scale: a scale measuring traits linked to reinforcement specific substance use profiles. Addictive Behaviors, Oxford, v. 34, n. 12, p. 1042-1055, 2009. PMid:19683400. http://dx.doi. org/10.1016/j.addbeh.2009.07.001
WORLD HEALTH ORGANIZATION - WHO. Substance abuse. WHO, 2013. Availble from: <http:// www.who.int/topics/substance_abuse/en/>. Access on: aug. 2013.

ZAVITSANOU, K.; GARRICK, T.; HUANG, X. F. Selective antagonist SR141716A binding to cannabinoid CB1 receptors is increased in the anterior cingulated cortex in schizophrenia. Progress in NeuroPsychopharmacology and Biological Psychiatry, Oxford, v. 28, n. 2, p. 355-360, 2004. PMid:14751433. http:// dx.doi.org/10.1016/j.pnpbp.2003.11.005 